\author{
Michael J. TURNER ${ }^{1}$ \\ University of Queensland \\ UQ Business School \\ St. Lucia Campus \\ QLD 4072 \\ AUSTRALIA \\ Phone: +61 733468071 \\ Fax: +61 733468199 \\ Email: m.turner@business.uq.edu.au
}

and

\author{
Chris GUILDING \\ Griffith University \\ Griffith Business School \\ Gold Coast campus \\ QLD 4222 \\ AUSTRALIA \\ Phone: + 61755528790 \\ Fax: +61 755528507 \\ Email: c.guilding@griffith.edu.au
}

\footnotetext{
${ }^{1}$ Corresponding Author
} 


\title{
AN INVESTIGATION OF AUSTRALIAN AND NEW ZEALAND HOTEL OWNERSHIP
}

\begin{abstract}
The results of a study seeking to advance a typology of hotel owners as well as examining the composition of hotel owners in Australia and New Zealand are reported. Interview observations resulted in the six hotel ownership categories, discernible from prior commentaries, being broadened to nine hotel owner types. Considerable insights with respect to differentials in the investment time horizon and capital expenditure strategy applied by different owner types were gleaned from the interview data. From a questionnaire survey phase it was found that high net worth private investors and hotel management companies each own approximately a quarter of large 3-5 star Australian and New Zealand hotels. Several distinct hotel operational characteristics are also apparent across the hotel owner types. These include the observation that developer, high net worth investor and strata titled owned hotels tend to be smaller in terms of revenue generated and also these owner types tend to own less hotels. Also, general managers tend to hold their position for shorter periods in hotels owned by hotel management companies and high net worth private investors tend to own older hotels.
\end{abstract}

Keywords: hotel owner classification, hotel industry, ownership, hotel 


\section{AN INVESTIGATION OF AUSTRALIAN AND NEW ZEALAND HOTEL OWNERSHIP}

\section{Introduction}

Despite a substantial broadening in the ownership base of the global hotel industry (Haast et al., 2006), literature concerning hotel owner types remains partial, fragmented and piecemeal and is based primarily on normative commentaries provided from a U.S. perspective (e.g. Canina, 2001; Field, 1995; Hanson, 2007; Oak \& Dalbor, 2008; Wallace \& Cossar, 2005). Hotel ownership types can differ significantly from country to country (Haast, et al., 2006; Newell \& Seabrook, 2006). Despite this, there has been minimal examination of the composition of hotel owners outside the U.S. Following the lead of Haast et al. (2008) and others, this study attempts to identify a typology of hotel owners in Australian and New Zealand. ${ }^{2}$ One of the primary contributions of this study is to synthesise and structure the prior fragmented work on types of hotel owners and provide insights into investment strategy differences across hotel owner types.

The study reported herein is believed to provide the most comprehensive listing of hotel owners to be found anywhere in the literature. Specifically, the study has pursued three objectives:

- $\quad$ to develop a typology of hotel owners found in Australia and New Zealand;

- to determine the distribution of Australian and New Zealand hotels across the owner categories identified; and

- to explore for hotel characteristics associated with the different hotel ownership categories.

\footnotetext{
${ }^{2}$ Wynne-Smith (2014) recently provided an update on the Haast et al. (2008) report.
} 
The study has been informed by two phases of empirical data collection. Firstly, interviews were conducted with twenty Australian hotel industry experts. Secondly, a questionnaire survey was administered to 145 Australian hotel general managers (GMs) and 55 New Zealand hotel GMs.

The remainder of the paper is structured as follows. The next section provides a review of the literature concerned with different hotel owner types. Following this, the method and findings of the study's exploratory interview phase are presented. Then the approach and findings of the study's questionnaire survey phase are outlined. The paper's final section provides a conclusion and discussion of issues arising.

\section{Literature review}

The advent and proliferation of alternative hotel operational forms, such as the management contract (see e.g., Beals \& Denton, 2005; Corgel, 2007; Panvisavas \& Taylor, 2006; Slattery, 1996; Smith Travel Research, 2003; Turner \& Guilding, 2010b), have signified a broadening in hotels' mode of owner / operator structuring since the late 1970s (see Dunning \& McQueen, 1982). ${ }^{3}$ At an international level of abstraction, the somewhat fragmented literature on hotel ownership types suggests the existence of six main types of hotel ownership. These comprise: (1) real estate investment trusts; (2) institutional investors; (3) developers; (4) high net worth investors; (5) specialist hotel management companies; and (6) strata-titled owners. A case can also be made for identifying an emergent hotel ownership grouping that is financed by sovereign wealth funds. This final grouping is heavily

\footnotetext{
3 A hotel management contract can be expressed as "An agreement between a property owner and a management company, who agrees to take on operational responsibilities. The owner, on the other hand, agrees to finance and build the property, if this is not yet done, and to pay for the management services" (Garcia-Falcon \& Medina-Munoz, 1999, p. 106).
} 
represented by Indian and Chinese corporations as well as companies from oil-rich countries (Haast, et al., 2008). The remainder of this section is structured according to these hotel ownership types.

\subsection{Real estate investment trusts}

A large proportion of hotels in western countries are owned by real estate investment trusts (REITs) (Nichols \& Boutell, 2005; Rowe, 2005). ${ }^{4}$ Most REITs are stock exchange listed (Larkin \& Lam, 2007; Rowe, 2005). ${ }^{5}$ In addition to hotels, REITs invest in a range of realestate forms including office, retail, residential, and industrial (Larkin \& Lam, 2007). REITs are generally tax-exempt, with tax payable only at the individual investor level on dividend income or any capital gain arising when an investor liquidates their REIT investment (Larkin \& Lam, 2007; Nichols \& Boutell, 2005). REITs enable investors to replicate returns arising from direct property ownership (Nichols \& Boutell, 2005). REITs operate within narrow parameters as they are required to distribute either 90\% (U.S. and Australia) or 95\% (UK) of their earnings to their investors (Beals \& Arabia, 1998; Mooradian \& Yang, 2001; Nichols \& Boutell, 2005). Hotels purchased by REITs tend to be at the mid-scale or high-end of the quality range and in good physical order (Brady \& Conlin, 2004).

\subsection{Institutional owners}

Unlike REITs, institutions are not required to distribute a certain percentage of profits to owners. Institutional owners can include lenders (Davis \& DeRoos, 2004), mutual funds (Firth, 1995; Heisler, Knittel, Neumann, \& Stewart, 2007), investment banks (Bielski, 2005; Norwell \& Mambrino, 2006; Oak \& Dalbor, 2008), insurance companies (Firth, 1995; Oak \&

\footnotetext{
${ }^{4}$ In January 2007 companies in the UK were allowed to enter into REIT regimes, however, UK REITs are generally restricted to hotel investment only (Larkin \& Lam, 2007). In most other developed countries, REITs are permitted to invest in a broad range of real estate assets (Nichols \& Boutell, 2005; Rowe, 2005).

${ }^{5}$ The terminology for REITs in Australia is different. Listed REITs are known as listed property trusts while unlisted REITs are known as unlisted property trusts (Haast, et al., 2008; Newell \& Peng, 2007; Rowe, 2005).
} 
Dalbor, 2008; Stewart, 2007), superannuation funds (Hollowell, 2006; Oak \& Dalbor, 2008), bank trusts (Clyde, 1997) and other similar organisations. Institutional investors appear to own a large proportion of the Australian hotel market, as it has been claimed that of Australia's US $\$ 140$ billion of total hotel investment product, US\$110 billion is held by institutional owners (Australia New Zealand \& Pacific Hotel Investment Conference, 2007). The recent trend of increasing institutionalised hotel ownership in Australia does not appear to be mirrored in the U.S. (Newell \& Seabrook, 2006).

\subsection{Developers}

Some developers retain ownership of a property for an extended period following its construction. The proportion of developer owners typically grows when the hotel market is in a cycle that favours the purchase and redevelopment of old properties (Hanson, 2007; Nelson, 2006; O'Neill, 2003). It is notable that local and state governments have offered inducements for developers to build and own hotels (Property Council of Australia, 2003).

\subsection{High net worth private investors}

High net worth private investors appear to be particularly prominent in Middle-Eastern countries, North Africa and China, but much less so in more developed markets (Younes \& Forster, 2006; Yu \& Huimin, 2005). It is also notable that Haast et al. (2006) document a growth in high net worth investors in the U.S. They observed that in 1998 high net worth private investors accounted for approximately $4 \%$ of all hotels purchased and that this had increased to $10 \%$ by 2000 . A similar trend is evident in Europe, as high net worth individuals made up approximately $10 \%$ of all purchasing activity in 2000, increasing to $12 \%$ by 2005 (Haast, Dickson, \& Braham, 2005). 


\subsection{Specialist hotel management companies}

Allison (2004) notes that specialist hotel management companies appear to comprise a significant proportion of European hotel owners. In the U.S., however, there appears to be a trend of hotel management companies liquidating their hotel property investments, due to a general perception that their profitability can be enhanced by restricting hotel involvement to a focus on operations management (Goodson, Dickson, \& Williams, 2006; Holmes, Jones, Lockwood, \& Miller, 2006; Page, 2007). Page (2007) notes that a downside of hotel management companies pursuing this property selling strategy is that they sacrifice a considerable degree of control following a sale, as they become accountable to the new hotel property owner for operational decisions taken.

\subsection{Strata titled hotel ownership}

'Strata title hotel ownership' is the term used in Australia when each hotel room has a separate property title. This form of hotel ownership is referred to as 'condominium hotels' in the US. Adler (2003) notes a substantial broadening in the extent that major hotel operators are becoming involved in managing strata-titled hotel properties, and Pizam (2006) commented on the extent to which growth of this form of hotel ownership has far outstripped research directed to the relatively new phenomenon. Warnken, Guilding and Cassidy (2008) provide a commentary on the international growth of tourism accommodation properties owned by way of strata title and identify factors contributing to this growth. These factors include the fact that strata titling facilitates the sale of rooms off the plan (thereby shortening the time period that a developer funds a new development and reducing developer risk exposure), and also the fact that strata titling broadens the pool of potential hotel owners to include small investors. It is notable that strata-titled hotels have the same appearance and feel as a traditional hotel, they just have a distinctly different ownership structure (Disick \& 
Noden, 1989). This factor underscores how strata titled hotel ownership growth has occurred in an unobtrusive manner. While growth in strata titled hotel ownership was rapid around the beginning of the $21^{\text {st }}$ century, Wolff (2007) feels that in the U.S., a lack of law and a framework upon which to base this business model has slowed the earlier boom in hotel strata titling. An overview of the different forms of management that can be found in strata titled tourism accommodation properties is provided by Cassidy and Guilding (2011).

\subsection{Emerging categories of hotel ownership}

There appear to be a number of emerging types of hotel owner, which include sovereign wealth funds, and corporations from India and China and oil-rich countries such as Russia (Haast, et al., 2008). ${ }^{6}$ An example of a sovereign wealth fund hotel owner is the Government of Egypt that has long been involved in hotel ownership and typically leases out the management rights to international hotel operators (Gray, 1998). Within the U.S., hotel ownership by sovereign wealth funds is a more recent phenomenon, as in 2007, only 2 per cent of hotel buyers in the U.S. were identified as sovereign wealth funds (Adler, Paider, \& Ferroni, 2007). In Australia, it is predicted that there will be an increase in hotel ownership from South-East Asian investors as well as investors from oil-rich nations, particularly at the high-end of the hotel market (Haast, et al., 2008).

\section{Exploratory interview phase}

The study's first empirical data collection phase involved the conduct of exploratory interviews with twenty Australian hotel industry experts over a six-month period in 2007. The research team maintains close contacts within the hotel sector and three large hotel management consulting companies endorsed the study and provided names of individuals

\footnotetext{
${ }^{6}$ Sovereign wealth funds are defined as "funds owned by a state composed of various financial assets" (Haast, et al., 2008, p. 34).
} 
whose experience signified they were well placed to provide insights on hotel ownership. Also, the initial interviewees provided further strong leads enabling the research team to broaden the interviewee sample. Twenty-five potential interviewees were contacted. Initial contact was made by the mailing of an interview package, which included information aimed at stimulating interest in the study and informing the potential participant that they would shortly be receiving a phone call from the research team to explore the possibility of their participation in the study. Twenty of the contacts agreed to be interviewed. Of the five contacts who did not wish to participate, three cited the problem of lengthy overseas commitments and two indicated a lack of available time. For those interviewees who were willing to be interviewed, a convenient time for the interview was organised and a copy of the interview schedule was forwarded (Baxter \& Chua, 1998). Each participant in the interview phase was promised confidentiality and his or her anonymity was assured.

All interviews were conducted in a face-to-face setting at each participant's place of work. In order to provide scope for gauging a broad range of perceptions on issues arising from different forms of hotel ownership, the interviewee sample represented six stakeholder groups: six asset managers, two hotel management contract lawyers, two hotel auditors, three hotel owner representatives, four hotel GMs and three hotel financial controllers. Table 1 provides an overview of the interviewee sample. The table's first column records the location of each interviewee's organisation and hence where the interviews took place. From this column it is evident that interviews were conducted with more than one interviewee in some organisations. The second column identifies each interviewee's position within their organisation. This column highlights the relative seniority of the interviewees in their respective organisations. Many of the interviewees had more than twenty-five years' 
experience in the hotel industry. The final column highlights important characteristics associated with the interviewee's role in their organisation and key organisation details.

\section{INSERT TABLE 1 ABOUT HERE}

Interviews varied in length from one and a half to three hours. Six short follow-up interviews of approximately fifteen minutes each were also carried out with three of the asset managers, two of the lawyers and one of the owners, in order to clarify a number of issues raised in the first round of interviewing. All of these follow up interviews were carried out in face-to-face settings in Sydney. A number of additional informal discussions also took place with other parties who were interested in the study. Each interviewee was forwarded an executive summary of the interview findings as both a token of the research team's appreciation for their participation in the study and also to seek feedback and confirmation of the findings, a step recommended by Atkinson and Shaffir (1998).

All interviews were tape recorded for transcription with the approval and consent of the interviewees and were fully transcribed. A relatively flexible approach was adopted with regard to the development and delivery of the interview schedule. Given the nature of the data sought, and the limited degree of academic understanding of some of the issues under examination, a semi-structured interactive data collection interview protocol was adopted. The manner of questioning used in connection with distilling the typology of hotel ownership types existing in Australia depended on the flow of each interview. During the interviews, several owner / operator dynamics were discussed (e.g., locus of power between hotel owners and operators, potential for biasing of capital budgeting cash flow projections by hotel operators, owner interests in FF\&E reserve accounting etc.). Often, while discussing one of 
these dynamics, unprompted dialogue regarding hotel ownership types resulted. The questioning was generally open-ended, which can be a particularly pertinent approach to assist in reducing the potential of bias resulting from researchers imposing opinions, attitudes or answers onto the interviewees (Easterby-Smith, Thorpe, \& Lowe, 2002). This approach also enabled clarification of ideas and opinions expressed by the interviewees. Accordingly, a relatively non-directive (Fontana \& Frey, 1994) qualitative data collection technique was employed. The recommendations of Baxter and Chua (1998) were also followed, whereby direct quotes are reported in the documentation of interview findings in order to convey rich, unbiased opinions that can enhance the validity of the narrative.

\subsection{Exploratory interview data findings}

Comments made by the interviewees provide grounds for suggesting that it is appropriate to conceive of Australian hotel owners as comprising nine main types. The suggestion of nine owner types signifies a departure from the literature described above. As already noted, this literature, which is heavily influenced by the U.S. experience, is suggestive of six main hotel owner types. There are two factors accounting for the disparity in what has been observed in this study. The first factor relates to REITs. The literature views REITs as constituting a single owner category. Comments made by the interviewees suggest that in Australia a distinction is generally made between listed REITs (generally referred to as listed property trusts or 'LPTs'), and unlisted REITs (generally referred to as unlisted property trusts or 'UPTs') (see also Haast, et al., 2008; Newell \& Peng, 2007; Rowe, 2005). The interviewees also referred to a third REIT category, which they labelled 'specific listed property trusts'. Specific listed property trusts invest in a particular type of real estate asset, such as hotels. An asset manager commented about the three different types of trusts as follows:

"The listed property trusts invest in various classes of real estate, and then you have the specific listed property trusts that focus solely on the hotel sector. These owners 
are focused on returns because they have listed stocks, which are valued every day by the market on their return, so they have to be tuned to performance and absolutely transparent in the market because they are listed. So, these two different types of owners are very focused on preserving the value of the hotel assets in the medium term. Unlisted property trusts, however, because they are not listed, short-term performance is less critical but year-on-year performance is still very important for the unit holders who are looking for that annual dividend cheque. ... They still focus on at least medium-term ownership.”

Another hotel ownership category that was observed, but does not appear to be identified in the literature is what the interviewees termed 'opportunity funds'. An asset manager provided the following description with respect to this hotel ownership sub-category:

"Then you've got opportunity funds. These are investors who are coming to find specific opportunities whether they be foreign or domestic. These types of investors are looking to find a 'story' in their investment, it might be a 'turnaround story'. What they want to do is buy that distressed hotel around the corner that is in receivership. Buy at a great price, throw a lot of money at it, lift the performance up, and generally speaking these opportunity funds have about a five-year window for investment. The opportunity fund's goal is typically to go in, buy a hotel, do some smart things with it, or find it in a cycle that is about to go up, do whatever they do, get out in a three to five-year period. ... These guys are not interested in maintaining the long-term integrity of the hotel."

The remainder of this section provides insights gleaned in the interviews with respect to facets of hotel management relating to the different forms of ownership. Negligible novel insights were made in connection with institutional owners. The consensus view held amongst the interviewees suggested that institutional investors have a long-term investment focus. This stems from the extent to which institutional investor financing is linked to the life insurance sector which is closely aligned to the pursuit of long term investment return targets.

It was interesting to note that there can be a range of scenarios resulting in a developer owning a hotel. A GM described how land speculation can trigger a developer's hotel ownership:

"A development company called (name withheld) purchased this site. I think that they saw an advertisement in the paper and they saw the plot of land and the real estate 
value of the land and they saw the potential of the land. They paid about $\$ 68$ million for the site and they did not even know that there was a successful hotel on the site. They had no idea that there was a hotel operation on the site. And never in their wildest dreams did they understand how successful it was. They were going to bulldoze the site and redevelop it within six to eight months but now they are going to hold the property for about four years until they enact their original re-development plan.”

This observation underscores how the speculative motive frequently lies behind a developer's ownership of a hotel property. It appears the strata titled form of ownership represents a vehicle that can support such speculative behaviour. This is because of the way in which strata-titling enables a developer to liquidate some or all of their investment, without having to wait for a large investor to purchase the hotel. In effect, the strata title ownership model has greatly broadened the hotel ownership market (Warnken, et al., 2008). A GM commented:

"A lot of developers are short-term thinking, but depending on ego, some are going to be more receptive to outside influences than others. ... Some of them really only want to buy the land that the hotel is sitting on, so what they will do is buy it and then start to sell the hotel off as strata apartments to give themselves enough money to carry out other developments on any free land that might be on the site.”

It was widely held by the interviewees that the strata titled form of property ownership is a significant and fast evolving form of Australian hotel ownership. A GM's insights on this trend, provided from a developer's perspective, underscore the extent to which this new form of hotel ownership is changing the hotel ownership landscape. He commented:

"Developers come in and only own a hotel for six months and then sell them all off as strata-titled apartments. They buy hotels and spend a hell of a lot of money on them and then sell them off as strata and make millions of dollars out of that ... they are not too concerned about the long-term of the hotel. Strata-titled hotel ownership is rapidly growing. I can give you plenty of examples of hotels that have been built and sold off the plan on a strata-basis by developers. The big advantage of doing the strata-titled selling is that a developer can get access to cash early on in their build from lots of small owners. .... If you can mitigate risk and get a better return on investment, why wouldn't you do it." 
A GM noted that while purchasers of strata titled hotel units are generally private individuals, they can also be corporations. Due to the differing profiles of owners within a single stratatitled hotel, it is difficult to classify strata-title hotel owners according to a short, medium, or long-term investment horizon. A GM commented:

"[Strata-titled hotel unit owners might] only own a hotel for six months as a sheer investment opportunity or they might buy it for lifestyle reasons without any preconceived agenda about when to sell.”

Interviewee comments suggest that considerable variation exists in the characteristics of hotel owners and their intended investment time horizon. Table 2 presents the nine categories of hotel owner along with additional information derived throughout the course of the interviews. The table's first column identifies the nine hotel owner categories, the second column outlines whether the hotel owner is public or private, and the third column highlights examples of owners falling within each category. The fourth column provides characteristics of each hotel owner and the final column outlines each owner types' typical investment time horizon.

\section{INSERT TABLE 2 ABOUT HERE}

The time horizon reported in the last column of Table 2 carries implications for hotel management, because short-term focussed owners appear to attach limited importance to maintaining a hotel's long-term integrity. For these types of owners, the projected timing of the asset sale appears to be based mainly on supply and demand considerations. Longer-term oriented owners, however, typically prefer to keep their money invested longer and are therefore likely to support more capital spending throughout their entire investment period. Almost all hotel owners, however, tend to limit capital spending late in their investment time 
horizon as it can sometimes take two to three years for capital spending to affect a hotel's cash flow. An asset manager commented:

"Usually you will come in and reposition the asset, trying to get some increase and then sell it. But the owner has to sell it sooner rather than later, otherwise they will have to do another refurbishment."

It appears public hotel owners with many shareholders exhibit a tendency to spread capital spending out as far as possible throughout their investment period so as to avoid the burden of any large cash flow outlay in any single year. A lawyer commented:

"Owners have to provide cash in the marketplace and they basically have to be able to provide a return that is commensurate with all of the other people in the same investment setting. Therefore, capital spending really creates a major issue for them because they basically have to provide a stable return for the investors. For example, an owner might have to deliver a 7.5\% return to the shareholders for the year and then on top of that, have enough money to complete required capital spending. So the timing of that capital spending puts a huge strain on the owners to clear that money. ... So owners try to spread the spending on capital out as far as possible, so that they are not hit with a huge amount at any one time."

Most hotel owners, however, appear to have a good understanding that potential buyers may wish to convert their hotel to an alternative use, which may render any capital spending toward the end of their investment time horizon of no value to the incoming owner. An owner captured the essence of this argument as follows:

"The investment time horizon of an owner can definitely affect the timing of their capital spending and there are definitely a lot of buyers out there that price hotels differently if they have an alternative use. For this reason, many owners these days, toward the end of their investment period, refrain from capital spending because they know full well that these types of new buyers are out there and they will price the hotel differently and if they conduct high capital spending toward the end of their investment time horizon, they might well be throwing money away.”

A general manager whose hotel was currently owned by a developer, who had purchased the hotel with the view to demolish it and replaced it with build apartments commented:

"The owners at this hotel are reluctant to spend money ... they are reluctant to give me the money for capital spending because they are looking at on-selling the property. .... We had to fight for two years to get them to spend just a couple of thousand dollars ... 
the place was just shocking ... and the owners were reluctant and then they would look at it again seriously and then they kept saying no. ... So we felt that our property lost credibility in the marketplace, totally, because we were advertising that next year we will have a new product and it will be refurbished and it would go into the brochures and then it didn't happen. ... If it happens once, you might get away with it, but if it happens twice, you just lose all of your credibility in the marketplace."

This refraining from capital expenditure strategy can, hopwever, work against an incoming owner who might wish to continue the current hotel's operations but have to confront a potential loss of credibility in the marketplace as a result of the hotel being too run-down.

The timing of capital spending can also depend on the market for selling hotels at the end of an owner's investment time horizon. For example, if the market is strong at the time of selling a property, purchasers are more likely to pay a premium for a hotel that is in particularly good condition. A long-term oriented owner commented:

"It is in our net interest to maintain the asset reasonably well, but we monitor how we spend capital relative to the market cycle, because if the market is very weak, you may not want to refurbish, because it might not make any difference when you sell. If the market is strong, you might have to do the refurbishment to maintain the competitiveness of the hotel and get a better price."

Despite this long-term oriented owner having a limited focus on short-term ownership objectives, he provided the following comment about the way in which he has seen shortterm oriented owners react to the same issue:

"Some short term owners basically come in and speculate and they are not necessarily natural hotel owners and they might only hold the hotel for two or three years and just play the market cycle and in most cases they spend very little on the asset. On the other hand, there are short-term oriented opportunity funds that buy a hotel that is run down and they come in, reposition it by spending $\$ 10$ or $\$ 15$ million and sell it. .... It depends on the cycle of the market though."

Adding further weight to the above comments, an asset manager noted that:

"You have to read the market. ... this goes back to looking at what is the market going to be like when you sell the property. If the market is likely to be strong ..., then people are more likely to pay a higher premium for a hotel that is in particularly 
good condition. There might, on the other hand, be the buyer that is looking to buy a rundown asset, flip it around, or re-badge it, or do something different with it. So if I were to buy a top-of-the-line, 5-star, hotel that is in immaculate condition, I would probably want to keep it that way. However, if I were to buy a rundown 4-star hotel, then I could carry out a fairly large amount of capital spending to bring it up to a 5star level, renegotiate and enter another management contract, then I would have a completely repositioned asset, only because I could spend the capital the way I wanted it to be spent. So horses for courses, there is no necessarily right or wrong answer to what the objectives of a hotel owner should be depending on their time horizon. The capital spending strategy depends to a large degree on what the hotel market is like at the time that the hotel owner wishes to sell the property as to what type of investment strategy they will adopt with regard to capital spending. ”

These comments suggest that despite the differing objectives of long and short-term focused hotel owners, a major overriding factor determining the timing of capital expenditure appears to be the state of the hotel property market. Whenever an owner elects not to carry out planned capital spending, for example, it comes at a cost to the hotel's existing operations. A financial controller commented:

"You can't really just say that you are not going to spend the capital and continue on because the result is that the repairs and maintenance bill is going to go up and your property operating expenses are going to go up and if the money isn't spent, the future value of the entity as a going concern will go down and that would be picked up in the financials because of your product deterioration and the resulting loss of revenue.”

These comments highlight the need for hotel owners to balance their capital spending toward the end of their investment period between the expected benefits to be gained by not spending, relative to the impact that a deteriorating product might have based on the market conditions for selling hotel properties at the time.

A further useful insight was given by a general manager who commented on a time when the Australian market was particularly weak. This enabled hotel owners to reap high rewards for hotels that were in particularly poor condition, as a result of deficient infrastructure investment. One of the main drivers for this situation was that there was increasing hotel ownership by property developers who refurbished "tired properties" and then sold them off 
as strata titled apartments because the residential market was stronger than the hotel market.

The general manager commented:

"At least $20 \%$ of the hotels on the Gold Coast are now owned by developer owners. The only negative with having a lot of developer owners in the industry is that there is the question of 'are they just care-taking the industry until they can find a better thing to do with it?' And does that mean from a long-term point of view that the size of the hotel industry is going to shrink?”

Despite the questions raised with respect to this trend of developers acquiring hotels, these comments signify that hotel infrastructure spending by an owner who is planning to sell their hotel could be wasted, as a new property developer owner would not reward the previous owner's expenditure if they are harbouring plans to fundamentally refocus the building's usage.

\section{Questionnaire survey phase}

Following the interview phase, a mailed questionnaire survey was administered. This sequence of empirical data collection provides tremendous potential for enhancing the understanding and interpretation of results obtained from statistical analyses (Hodgkinson \& Payne, 1998; Wilk, 2001). Such an approach can also allow for a triangulation of research methods and the adoption of a mixed methods research paradigm (Hayne \& Pollard, 2000; Judge, Thoresen, Bono, \& Patton, 2001; Shaffer \& Harrison, 2001). Mixed methods research can result in enhanced and new lines of thinking, and confirmation and elaboration because the weaknesses of one approach can be compensated for by the strengths of the other approach (Birnberg, Shields, \& Young, 1990; Miles \& Huberman, 1994; Rossman \& Wilson, 1991). The combination of face-to-face interviews and a mailed questionnaire survey can add to the validity of the information gathered in a study (Abernethy, Chua, Luckett, \& Selto, 1999; Miles \& Huberman, 1994; Sutton \& Rafaeli, 1998). 
The mailed questionnaire survey was sent to GMs in Australian and New Zealand hotels with twenty or more rooms and a minimum star-rating of three in June and July 2008. The questionnaire was sent to GMs as they were seen as holding the requisite knowledge required to address the questions and comprised a large enough group to enable the collection of sufficient responses to enable a robust analysis. The 2006/2007 RACQ Hotel Accommodation Guide provided the study's sampling frame for Australian hotels. The sampling frame for the New Zealand (NZ) sample was drawn from cross checking against two comprehensive online databases, comprising 'wotif.com' and 'asiahotels.com'. This provided a total sample size of 664, comprising 463 Australian hotels and 201 New Zealand hotels. Mailed packages sent to each GM contained a questionnaire, a covering letter, a flyer indicating endorsement of the study by three leading hotel consultancy companies, a further flyer that provided a photograph of the researchers and brief research biographies, and a reply paid envelope. The questionnaire was extensively pilot tested using fourteen academics and six practitioners. Three weeks subsequent to the initial mailing, a follow-up mailing was sent to the entire sampling frame. Two weeks after the second mailing, a number of hotel owner representatives familiar to the research team agreed to circulate the questionnaire to GMs with whom they had close contact. This generated a further 51 responses. Two weeks subsequent to the owner representatives' distribution of questionnaires, the sample was contacted by email and encouraged to complete the questionnaire which was provided as an attachment. Finally, two weeks after the email approach, random telephone calls were made to 31 GMs. The objective of these phone calls was threefold: to thank the GM if they had already completed the survey; to ascertain the main reasons for non-participation in the study; and to encourage participation in the study. The survey response pattern is reported in Table 3. 


\section{INSERT TABLE 3 ABOUT HERE}

Two investigations for non-response bias were undertaken. Non-response reasons provided by the hotels contacted by phone included "completing questionnaires contravenes company policy", "too busy" and "the GM was away on holiday". No factors cited suggested the

presence of any systematic non-response bias. Secondly, an investigation for profile differences between the first mailing respondents and the remainder of the respondents was undertaken. Although a Mann-Whitney $U$ Test revealed some differences, the statistical strength of association between the two groups ( $r$ value) was small (i.e. $r<.2$ ) (see Cohen, 1988). These investigations suggest the issue of non-response bias does not constitute a strong threat to the validity of the study's findings.

\subsection{Variable measurement}

The questionnaire was designed to determine the hotel ownership category for each of the hotels represented in the sample. In addition, to investigate for any relationships between types of hotel ownership and hotel characteristics, items in the questionnaire were designed to measure: type of owner / operator structure (i.e., owner-operator, management contract, franchise, other), hotel star rating, hotel age, time the GM has been in current position, hotel size, and hotel owner size. The manner in which variables were measured is not thought to pose any strong threat to the validity of the questionnaire survey findings. Measures were extensively pilot tested (Roberts, 1999), fully explained, and based as far as possible on prior research (Neuman, 2003). 
Following the question: "Which of the following categories best describes the owner of your hotel?”, respondents were presented with the nine hotel owner categories identified during the exploratory interview phase. In addition to the nine, an "other" category was offered in case a respondent felt their hotel did not correspond to any of the nine category options. The questionnaire also provided a short description of each of the ownership categories as follows:

1. Unlisted property trust (these are typically trusts that are not listed on the stock exchange, e.g. Colonial First State).

2. Listed property trust (these types of owner typically invest in various classes of real estate, of which hotels are only one. A general property trust is listed on the stock exchange, e.g. Thakral, Mirvac).

3. Specific listed property trust (this type of trust invests solely in hotels and is listed on the stock exchange, e.g. Grand Hotel Group).

4. Opportunity fund (opportunity funds are typically investment banks that hold hotels for only relatively short periods of time, e.g. Morgan Stanley).

5. Traditional investment institution (this type of owner is typically made up of large insurance companies and listed on the stock exchange, e.g. AMP, GIC).

6. Specialist hotel management company (this type of company specialises in managing hotels, e.g. Accor).

7. Developer (this type of owner has retained ownership of the hotel following management of its development, e.g. Sunland Group, Raptis Group).

8. Strata titled ownership (accommodation rooms are individually owned under separate property titles).

9. High net worth private investor (this type of owner can be an individual or a consortium of individuals holding the hotel as a privately funded asset, e.g. Mulpha). 
The literature highlighted that the main methods of hotel ownership structure are the independent owner-operator, franchise and management contract arrangements (Gannon \& Johnson, 1997). Questions from prior studies (Guilding, 2003; Lamminmaki, 2003) measuring whether a hotel operates with a management contract were adapted whereby respondents were asked to choose between the three operational modes outlined above, as opposed to a yes/no answer. To prevent confusion between the three choices, respondents were provided with short definitions of each term. The definitions for management contracts and franchises were drawn from Garcia-Falcon and Medina-Munoz (1999, p. 106), which were based on Angelo and Vladimir (1994), Kasavana and Brooks (1995), Knowles (1996) and Vallen and Vallen (1999). The definition for independently owned and operated hotels was based on Field's (1995) work. An "other" option was also provided in case there were any additional hotel operating arrangements that were not identified during the literature search or conduct of the interviews. If a respondent chose this "other" option, they were asked to describe the nature of the owner / management structure. Specifically, the questionnaire asked "Which of the following best describes your hotel's ownership / management structure? Please tick.”

- Management Contract (There is an agreement between a property owner and a hotel operating company. The hotel operating company takes on operational responsibilities. The owner owns the property and pays the hotel operating company a fee for managing the hotel).

- Franchise (For a fee, an independent hotel adopts the franchiser's name and trademarks and receives services in return. Almost all the advantages of the chain are available for the franchisee: mass purchasing, management consultation, wide advertising, central reservations, and systems designs). 
- Independently Owned and Operated (The entity operating the hotel is the same as the entity owning the hotel and no management contract or franchising arrangement has been entered into).

- Other (Please describe)

Star-rating has been widely measured in hotel research (see e.g. Burgess, 2003; Guilding \& Lamminmaki, 2007; Harrington \& Keating, 2006; McKay, Clack, Batchelor, Astbury, \& Teerapittayapaisan, 2002; Nebel, Braunlich, \& Zhang, 1994). The current study used Guilding and Lamminmaki’s (2007) measure of star-rating by asking the respondent: "What is the star-rating of your hotel?”

After an extensive literature search, only two studies were found that had sought to measure the age of a hotel property using a questionnaire survey (Brooke \& Denton, 2007; Mellen, Nylen, \& Pastorino, 2000). These studies simply posed the following statement "Year built". In the current study, this question was modified to read: “Approximately how many years old is your hotel?”, with space provided for a response.

An earlier study that sought to measure the number of years that the incumbent GM had been in their position was carried out by McManus (2006), who asked "Your length of employment: in current position __ years”. Adapting this, the respondent was asked “Approximately how many years have you been GM at this property?”, with space provided for a response.

A range of approaches have been taken to measure hotel size, e.g. acres of land, number of employees, number of rooms, annual sales turnover and net profits (Vallen \& Vallen, 2005). 
It appears that number of rooms is the most widely adopted measure (Garcia-Falcon \& Medina-Munoz, 1999; Vallen \& Vallen, 2005), although annual sales turnover has also been widely adopted (Guilding \& Lamminmaki, 2007; Lamminmaki, Guilding, \& Pike, 1996; Property Council of Australia, 2003). It was therefore felt prudent to use both measures. To determine the number of rooms in a hotel, questionnaire measures are typically categorical (e.g. Kasavana \& Brooks, 1995; Vallen \& Vallen, 2005) or discrete (e.g. Guilding \& Lamminmaki, 2007). In light of the advantages of discrete data, respondents were asked:

"What is the approximate size of your hotel? a) number of rooms: __". Following this, in order to measure annual sales turnover, a measure used by Guilding and Lamminmaki (2007) was adopted whereby the respondent was asked: "What is the approximate size of your hotel in annual sales turnover? AUD\$ million”

Little empirical academic research was found that had attempted to measure hotel owner size. Industry publications such as Haast et al. (2006, p. 24), however, typically use the number of rooms owned as a measure of a hotel owner's size. The interview findings also highlighted that in addition to the number of rooms owned, a further measure of a hotel owner's size might be the number of hotels that they own. For this reason, it was thought pertinent to use both measures. Respondents were asked “What is your hotel owner's approximate size?” and then asked to indicate the "Number of hotels owned (i.e. worldwide): ” and also the “Number of hotel rooms owned (i.e. worldwide):

\subsection{Questionnaire survey findings}

The first column of Table 4 identifies the 9 specific hotel owner categories as well as the $10^{\text {th }}$ category termed 'other'. The second column records the sample's frequency distribution across these 10 hotel owner categories. For each owner category, the collected data was 
further analysed to determine the incidence of different owner / operator arrangements (reported in the next four columns). The subsequent seven columns provide the mean of the seven hotel characteristics that have been gauged.

\section{INSERT TABLE 4 ABOUT HERE}

With respect to the allocation of the sample across the 10 hotel owner categories, two categories account for approximately half of the sample. High net worth private investors had the highest incidence of ownership (27\%) and specialist hotel management companies had the second highest incidence of ownership (23.5\%). Opportunity funds had the lowest incidence of ownership (1.5\%). Of the 3.5\% $(n=7)$ respondents that responded "other", responses were as follows: (1) joint venture, combining a developer and a specific listed property trust; (2) hotel is currently under receivership; (3) hybrid mix, strata titled / timeshare / developer; (4) owned by timeshare club with a right to use; (5) local government - local Maori Tribe; (6) sovereign wealth fund. One respondent did not provide any comment.

For hotel ownership / management structures, adoption of the management contract was found to be dominant (50.5\%), followed by the owner-operator (37\%) and franchise (9\%). Of the seven respondents who responded 'other', six indicated that their hotels operated under a lease. One respondent did not provide any comment.

With respect to star-rating, hotels owned by unlisted property trusts recorded the lowest average star rating (4.04) while traditional investment institutions own hotels with the highest average star rating (4.50). Caution needs to be exercised if attempting to interpret these 
observations, as application of a one-way between groups ANOVA with planned comparisons failed to reveal any statistically significant differences across the hotel owner categories with respect to star-rating.

With respect to hotel age, the average age of high net worth private investor hotels is statistically significantly greater than the remainder of the sample $(p<.05)$, and it also appears unlisted trusts tend to own older hotels (statistically significantly greater than the remainder of the sample; $p<.10$ ). Strata titled hotels and hotels owned by developers are statistically significantly younger than the remainder of the sample $(p<.01)$.

With respect to the average number of years that the incumbent GM has held their position, the data revealed that GMs in specialist hotel management companies held their position for a statistically significantly shorter time than the rest of the sample $(p<.01)$. This was the only statistically significant difference observed in connection with the length of time GMs have held their current position.

With respect to hotel size, Table 4 reports that both developer owned hotels and high net worth private investor owned hotels tend to be relatively small with a fewer number of rooms $(p<.05)$ and lower hotel revenues $(p<.01)$, relative to the remainder of the sample. It is also apparent that strata titled hotels tend to have low revenue relative to the remainder of the sample $(p<.01)$

Table 4's final two columns provide insights with respect to the average size of the different types of owner. Specialist hotel management companies can be viewed as large, both from a number of hotels owned perspective $(p<.01)$ and total number of rooms perspective $(p<$ 
.01). Opportunity funds also appear to be large from a number of hotel rooms perspective ( $p$ $<$.05). Unlisted property trusts, traditional investment institutions, developers, strata-titled owners, and high net worth private investors have all been found to be small on the number of hotels owned dimension $(p<.10)$. These observations are supported by the table's final column of data, as developers, strata-titled owners, and high net worth private investors appear to be small with respect to number of hotel rooms at the ' $p<.01$ ' level of significance and unlisted property trusts and traditional investment institutions are small on the same dimension at the $5 \%$ threshold of statistical significance.

\section{Discussion and conclusion}

The first objective of the study reported herein was to develop a typology of Australian and New Zealand hotel owners. A distinct contribution of the study concerns the view that the number of hotel ownership categories can be usefully extended beyond the six that is identifiable in the literature, to nine. Several subjects interviewed in the study felt that it is appropriate to view REITs as comprising three distinct types: listed property trusts, unlisted property trusts and specific listed property trusts. In addition, some interviewees saw merit in recognising opportunity funds as a distinct hotel ownership category. Some support for distinguishing between listed and unlisted property trusts is provided by the literature (Haast, et al., 2008; Newell \& Peng, 2007; Rowe, 2005). Accordingly, identification of specific listed property trusts, as a third REIT category, in addition to the inclusion of opportunity funds as an ownership category, represents a distinctive contribution provided by the study with respect to hotel owner typology refinement.

Another 'classificatory' finding concerns the six survey respondents that identified themselves as working in a leased hotel. This suggests that the hotel ownership / management 
structure proposed by Dunning and McQueen (1982), with leasing as a fourth option, may be appropriate for use in any future research studies concerned with ownership / management structures. Indeed, the leasing of hotels may be a phenomenon worthy of recognition in any future research concerned with hotel ownership issues. It is also notable that the literature suggests the existence of a hybrid owner / operator arrangement that has been termed a "manlease”. This is similar to a lease arrangement but includes many of the commercial terms generally applied in management contracts (Dickson, 2007, p. 4). Under this arrangement, the risk of hotel operations remains with the owner. Although the study did not uncover any examples of 'man-lease" operations, this may have been because no reference was made to this type of structure in the survey questionnaire. Dickson (2007) commented on how this particular structure can be used in certain jurisdictions to deal with particular business contextual issues arising under local law (e.g. tax laws). Further research could usefully focus on the particularities of applying the "man-lease" hotel operating governance structure.

The study's second objective was to determine the distribution of Australian and New Zealand hotels across the owner categories identified. Some credibility is provided to viewing REITs as comprising three distinct types, as while $23 \%$ of the total hotels in the sample were owned by a REIT, $59 \%$ of the REIT sub-sample are owned by listed property trusts, $28 \%$ of the sub-sample are owned by unlisted property trusts, and $13 \%$ of the sub-sample are owned by specific listed investment trusts. In addition, a differential within the broad REIT category is apparent, due to a suggestion that hotels owned by unlisted property trusts may tend to be relatively older. Another notable aspect of the survey results is that they challenge the literary proposition that institutional investors own a large proportion of the hotel market. Only $2.5 \%$ of the survey sample reported ownership from a traditional investment institution. There is also a literary claim that the proportion of developer owners typically increases when the 
hotel market is in a cycle that favours the purchase and redevelopment of old properties (Hanson, 2007; Nelson, 2006; O'Neill, 2003). This signifies that the proportion of hotels owned by developers is likely to vary in line with the property market cycle. Further survey work would be required to examine whether the $11.5 \%$ developer ownership of hotels is an enduring feature of Australian and New Zealand hotel ownership. In terms of evolving trends, it appears that strata title is a fast emerging form of hotel ownership (Pizam, 2006; Warnken, et al., 2008). While this study has found that $7.5 \%$ of the sample has strata-titled ownership, there appears to be due cause to expect this proportion to rise in the future, further motivating the need for future survey work, should insights into contemporary hotel ownership patterns be sought. As a final comment on the observed distribution of hotel owner types, the literature suggests that high net worth private investor hotel ownership tends to be low in a developed market (Younes \& Forster, 2006; Yu \& Huimin, 2005). While this again highlights the need for on-going survey work to monitor evolving hotel ownership trends, it is notable that the current study reveals that of all the hotel owner categories examined, the greatest proportion of Australian and New Zealand hotels are owned by high net worth private investors. Finally, six respondents (3.5\% of the sample) indicated that their hotel owner type did not readily align to any of the nine ownership categories identified from the literature review and interview phases of the study. Each of these respondents referred to a different ownership arrangement. These were: (1) joint venture between a developer and a listed property trust; (2) sovereign wealth fund; (3) co-owned by a developer and strata title and timeshare ownership arrangements; (4) owned by a timeshare club with a right to use; (5) co-owned by local government and a Maori Tribe; (6) hotel under receivership. While the literature identified sovereign wealth funds as an emerging hotel ownership category (e.g., Adler, Paider, \& Ferroni, 2007; Gray, 1998; Haast et al., 2008), other hybrid forms of hotel ownership do not appear to have been recognised in the literature. Examination of the 
organisational and operational dynamics applying in these alternative ownership arrangements could provide a fruitful avenue in further research endeavours.

The study's final objective concerned undertaking an examination for hotel characteristics associated with the different hotel ownership categories. Data collected during the study's interview phase suggest substantial hotel owner type variations on key business dimensions such as strategy pursued and also investment time horizons. It is notable that the relatively developed literature concerning hotel capital budgeting (e.g., Turner \& Guilding, 2010a; 2010b; 2012; 2013) has failed to explore for any significant roles played by owner type in connection with capital budgeting dynamics. There has also been significant literature examining the optimal timing of real estate investment. In this literature it is reported that if there are unanticipated changes in the hotel market, such as from an economic downturn, then a strategy of high capital spending may fail to deliver targeted increases in revenue and property values (Williams, 1997; Wong \& Norman, 1994). When the hotel property market is depressed or experiencing extreme levels of volatility, the preferred capital spending strategy will be to defer property acquisitions (Chu \& Sing, 2007). Application of this strategy has to be weighed, however, against any competitive disadvantage resulting from a competitor securing first mover advantage resulting from pre-emptive market entry (Grenadier, 2002; Wang \& Zhou, 2006; Williams, 1993). Where a hotelier feels exposed to such a competitive threat, irrational over-expenditure on building infrastructure can result (Grenadier, 2002). Chu and Sing (2007) note that when the hotel property market is strong, there is a greater incentive for owners to increase their capital expenditures. Insights from the empirical findings reported herein suggest these studies have been conducted from a somewhat generalised perspective, however, as they fail to recognise different expenditure strategies employed by different hotel owner types. 
In connection with questionnaire findings and the study's final objective, some of the more notable findings arising from this facet of the study will now be commented upon. Specialist hotel management companies own nearly a quarter of the hotels surveyed. Given the international profile of many specialist hotel management companies, it is logically consistent to find that, relative to the rest of the sample, these owners are relatively large (with respect to the total number of hotels and hotel rooms that they own). This is despite U.S. commentaries suggesting decreasing levels of hotel ownership by specialist hotel management companies (Page, 2007). It also appears intuitively consistent that GMs working in hotels owned by hotel management companies tend to have held their current position for a short period of time relative to other hotel owners. This is because hotel management companies have a well-established culture of rotating their GMs across hotels within the company.

Developer owners appear to be significantly different from the remainder of the sample across several of the operational characteristics examined. Hotels owned by developers are relatively young, they are relatively small and developers tend to own relatively few hotels. All of these observations appear consistent with what one would have reasonably anticipated. As it may take a few years for a developer to sell a hotel, there is likely to be a high incidence of developers owning relatively young hotels that they are actively seeking to sell. Also, as hotel ownership does not represent the core business for most developers, they are likely to hold on to a hotel for an extended period only if it is relatively small, and the number of hotels that they own are likely to be relatively few. In addition, developers may seek to purchase small hotels in order to facilitate their capacity to renovate or rebuild. It could also be the case that the relatively small size of developer owners apparent from Table 4 may 
result from there being limited development opportunities within the market at the time of the survey's administration. This might change when the economy is in an expansionary period.

As strata titled ownership represents a relatively new phenomenon on the ownership landscape, it appears logically consistent that strata titled owned hotels would tend to be relatively young compared to the remainder of the sample. It has also been found that strata titled hotels are relatively small in terms of revenue. This may result from such complexes having relatively low levels of investment in non-accommodation infrastructure such as restaurants and bars. Finally, as there will be a high proportion of individuals owning a unit or room in a strata titled hotel, it is to be expected that these owners will score relatively lowly in terms of the number of hotels and hotel rooms that they own.

The final ownership grouping that exhibits several distinctive operational characteristics with respect to the hotels that they own are the high net worth private investors. The relatively older age of hotels owned by this group of owners may partially stem from the family nature of many such ownership ventures. In addition, it could be the case that this type of owner was more active in the market several years ago, and once they own their 'trophy', such owners are likely to be resistant to sell, and are relatively insulated from any commercial imperative to sell. This is likely to especially be the case given ego-trip ownership is frequently associated with this type of owner (Guilding, 2006). It also appears as logically consistent that such owners own relatively small hotel properties and that the total number of hotel properties that they own are relatively small. All of these expectations are supported by the data reported in Table 4. 
Finally, the questionnaire provided insights with respect to the incidence of different hotel owner / operator structures. Adoption of the management contract was dominant (50.5\%), followed by the owner-operator (37\%) and franchisee arrangement (9\%). The observed predominance of management contracts mirrors the findings of prior research (e.g., Contractor \& Kundu, 1998; Slattery, 1996; Smith Travel Research, 2003). Given the not inconsiderable theoretic challenges arising between hotel owners and operators in the management contract setting (Turner \& Guilding, 2010b), further research might usefully benefit from examining the role that ownership type can play in the nature of owner / operator dynamics.

The primary contribution of this study is that it is believed to be the first to shed any light on the nature of hotel property ownership outside the U.S. The lack of research interest in hotel ownership is surprising when it is recognised that there is considerable scope for distinct ownership styles affecting the manner of hotel management control and key hotel operating decision making (Turner \& Guilding, 2010a, 2010b, 2012, 2013).

When seeking to interpret the findings reported in this paper, the normal provisos that apply to research that is based on qualitative data collected via exploratory interviews and also quantitative data collected via a questionnaire survey should be born in mind. Nevertheless, some of these shortcomings may have been mitigated somewhat, as a result of applying both research methodologies in the study. The validity of the observations reported herein can only be gauged following the conduct of further investigations of the composition of hotel ownership. In light of the dearth of attention that the hotel ownership issue has commanded, such further work is to be welcomed. 


\section{References}

Abernethy, M. A., Chua, W. F., Luckett, P. F., \& Selto, F. H. (1999). Research in managerial accounting: Learning from others 'experiences'. Accounting and Finance, 39(1), 1-27.

Adler, A. (2003). FocusOn condo-hotels: Expanding the options for lodging development (Vol. October, pp. 1-11): Jones Lang LaSalle Hotels.

Adler, A., Paider, K., \& Ferroni, L. (2007). Hotel investment highlights: U.S. transactions 2007 (Vol. March, pp. 1-12): Jones Lang LaSalle Hotels.

Allison, S. (2004). Inward investment into the European hotel investment market. Journal of Retail \& Leisure Property, 4(1), 50-60.

Angelo, R. M., \& Vladimir, A. N. (1994). Hospitality today: An introducation (2nd ed.). Michigan: The Educational Institute of the American Hotel and Motel Association.

Atkinson, A., \& Shaffir, W. B. (1998). Standards for field research in management accounting. Journal of Management Accounting Research, 10, 41-68.

Australia New Zealand \& Pacific Hotel Investment Conference. (2007). New money, new focus. Paper presented at the Australia New Zealand \& Pacific Hotel Investment Conference, Sydney, Australia.

Baxter, J. A., \& Chua, W. F. (1998). Doing field research: Practice and meta-theory in counterpoint. Journal of Management Accounting Research, 10, 69-87.

Beals, P., \& Arabia, J. V. (1998). Lodging REITs. Cornell Hotel and Restaurant Administration Quarterly, 39(6), 52-59.

Beals, P., \& Denton, G. A. (2005). The current balance of power in North American hotel management contracts. Journal of Retail \& Leisure Property, 4(2), 129-146.

Bielski, L. (2005). Lenders go "quant". American Bankers Association. ABA Banking Journal, 97(11), 36-40.

Birnberg, J. G., Shields, M. D., \& Young, S. (1990). The case for multiple methods in empirical research in management accounting (with an illustration from budget setting). Journal of Management Accounting Research, 2(Fall), 1-40.

Brady, P. J., \& Conlin, M. (2004). The performance of REIT-owned properties and the impact of REIT market power. Journal of Real Estate Finance and Economics, 28(1), 81-95.

Brooke, J., \& Denton, G. A. (2007). CapEx 2007: A study of capital expenditures in the hotel industry (pp. 1-98). Alexandria, VA: International Society of Hospitality Consultants.

Burgess, C. L. (2003). Gender and salaries in hotel financial management: It's still a man's world. Women in Management Review, 18(1/2), 50-59.

Canina, L. (2001). Acquisitions in the Lodging Industry: Good news for buyers and sellers. Cornell Hotel and Restaurant Administration Quarterly, 42(6), 47-54.

Cassidy, K., \& Guilding, C. (2011). A typology of Australian tourism based condominiums. International Journal of Contemporary Hospitality Management, 23(3), 312-326.

Chu, Y. Q., \& Sing, T. F. (2007). Optimal timing of real estate investment under an asymmetric duopoly. Journal of Real Estate Finance and Economics, 34(3), 327-345.

Clyde, P. (1997). Do institutional shareholders police management? Managerial and Decision Economics, 18(1), 1-10.

Cohen, J. (1988). Statistical power analysis for the behavioral sciences (2nd ed.). Hillsdale, NJ: Lawrence Erlbaum Associates.

Contractor, F. J., \& Kundu, S. K. (1998). Modal choice in a world of alliances: Analyzing organizational forms in the international hotel sector. Journal of International Business Studies, 29(2), 325.

Corgel, J. (2007). Technological change as reflected in hotel property prices. The Journal of Real Estate Finance and Economics, 34(2), 257-279. 
Davis, G., \& DeRoos, J. (2004). Structuring hotel deals to achieve strategic goals: An owner's perspective. Journal of Retail \& Leisure Property, 4(1), 18-31.

Dickson, G. (2007). Ten hot management agreement issues in Asia. Hotels Resorts \& Tourism Newsletter, June, 1-11. Retrieved from http://www.bakernet.com/NR/rdonlyres/86BE8EF9-2715-4591-86977E25966CFD58/42504/HRTNewsletterJuly2007.pdf

Disick, D. M., \& Noden, M. A. (1989). Hotel condominiums after tax reform. Cornell Hotel and Restaurant Administration Quarterly, 29(4), 20-30.

Dunning, J. H., \& McQueen, M. (1982). Multinational corporations in the international hotel industry. Annals of Tourism Research, 9, 69-90.

Easterby-Smith, M., Thorpe, R., \& Lowe, A. (2002). Management research: An introduction (2nd ed.). London: Sage.

Field, H. M. (1995). Financial management implications of hotel management contracts: A UK perspective. In P. J. Harris (Ed.), Accounting and finance for the international hospitality industry. Oxford: Butterworth-Heinemann.

Firth, M. (1995). The impact of institutional stockholders and managerial interests on the capital structure of firms. Managerial and Decision Economics, 16(2), 167-175.

Fontana, A., \& Frey, J. H. (1994). Interviewing: The art of science. In N. K. Denzin \& Y. S. Lincoln (Eds.), Handbook of qualitative research (pp. 361-377). London: Sage.

Gannon, J., \& Johnson, K. (1997). Socialization control and market entry modes in the international hotel industry. International Journal of Contemporary Hospitality Management, 9(5/6), 193-209.

Garcia-Falcon, J. M., \& Medina-Munoz, D. (1999). The relationship between hotel companies and travel agencies: An empirical assessment of the United States market. The Service Industries Journal, 19(4), 102-123.

Goodson, M., Dickson, G., \& Williams, R. (2006). What's hot and what's not with management agreements? (Vol. April, pp. 1-10). Sydney: Baker \& McKenzie.

Gray, M. (1998). Economic reform, privatization and tourism in Egypt. Middle Eastern Studies, 34(2), 91-112.

Grenadier, S. R. (2002). Option exercising games: An application to the equilibrium investment strategies of firms. Review of Financial Studies, 15, 691-721.

Guilding, C. (2003). Hotel owner/operator structures: Implications for capital budgeting process. Management Accounting Research, 14(3), 179-199.

Guilding, C. (2006). Investment appraisal issues arising in hotels governed by a management contract. In P. J. Harris \& M. Mongiello (Eds.), Accounting and financial management: Developments in the international hospitality industry (pp. 400 - 422). Oxford: Butterworth-Heinemann.

Guilding, C., \& Lamminmaki, D. (2007). Benchmarking hotel capital budgeting practices to practices applied in non-hotel companies. Journal of Hospitality and Tourism Research, 31(4), 486-503.

Haast, A., Adler, A., Wynne-Smith, M., Gibson, D., Nair-Grepinet, A., Ottevaere, J., . . . Wales, K. (2006). The hotel ownership pendulum in motion (pp. 1-40): Jones Lang LaSalle Hotels.

Haast, A., Adler, A., Wynne-Smith, M., Gibson, D., Nair-Grepinet, A., Van den Brande, K., . .. Ferroni, L. (2008). Hotel investment outlook: Jones Lang LaSalle Hotels.

Haast, A., Dickson, G., \& Braham, D. (2005). Global hotel management agreement trends. June, 1-24. Retrieved from https://classshares.student.usp.ac.fj/TS108/12009/Course\%20Weekly\%20Readings/W k\%202\%20Global\%20hotel\%20management\%20agreement\%20trends.pdf 
Hanson, J. (2007). New construction continues to rise, PwC says. Real Estate Forum, 62(1), 63.

Harrington, D. J., \& Keating, M. (2006). Quality management initiatives in Irish hotels: Emerging agendas in a changing environment. Tourism and Hospitality Research, 6(4), 267-283.

Hayne, S. C., \& Pollard, C. E. (2000). A comparative analysis of critical issues facing Canadian information systems personnel: A national and global perspective. Information \& Management, 38(2), 73-86.

Heisler, J., Knittel, C. R., Neumann, J. J., \& Stewart, S. D. (2007). Why do institutional plan sponsors hire and fire their investment managers? The Journal of Business and Economic Studies, 13(1), 88-119.

Hodgkinson, G. P., \& Payne, R. L. (1998). Graduate selectin in three European countries. Journal of Occupational and Organizational Psychology, 71(4), 359-365.

Hollowell, B. (2006). The effects of institutional investors in the retail industry. Journal of American Academy of Business, Cambridge, 9(2), 27-32.

Holmes, K., Jones, P., Lockwood, A., \& Miller, G. (2006). An eccectic agenda for Tourism and Hospitality Research. Tourism and Hospitality Research, 7(1), 76-83.

Judge, T. A., Thoresen, C. J., Bono, J. E., \& Patton, G. K. (2001). The job satisfaction-job performance relationship: A qualitative and quantitative review. Psychological Bulletin, 127(3), 376-407.

Kasavana, M. L., \& Brooks, R. M. (1995). Managing front office operations (1st ed.). Michigan: The Educational Institute of the American Hotel and Motel Association.

Knowles, T. (1996). Corporate strategy for hospitality (1st ed.). Essex: Longman.

Lamminmaki, D. (2003). Outsourcing in the hotel industry: A management accounting perspective. Doctor of Philosophy, Griffith University, Gold Coast, Australia.

Lamminmaki, D., Guilding, C., \& Pike, R. (1996). A comparison of British and New Zealand capital budgeting practices. Pacific Accounting Review, 8, 1-29.

Larkin, D., \& Lam, C. (2007). Hotels - The fifth food group? Journal of Retail \& Leisure Property, 6(1), 23-28.

McKay, M., Clack, V., Batchelor, M., Astbury, K., \& Teerapittayapaisan, S. (2002). Changing ownership structures (Vol. December, pp. 1-16). London: Jones Lang LaSalle Hotels.

McManus, L. (2006). An examination of customer accounting in an Australian context. Doctor of Philosophy, Griffith University, Gold Coast, Australia.

Mellen, S., Nylen, K., \& Pastorino, R. (2000). CapEx 2000: A study of capital expenditures in the U.S. hotel industry (pp. 1-150). Alexandria, VA: International Society of Hospitality Consultants.

Miles, M. B., \& Huberman, A. M. (1994). An expanded sourcebook: Qualitative data analysis (2nd ed.). Thousand Oaks, CA: Sage.

Mooradian, R. M., \& Yang, S. X. (2001). Dividend policy and firm performance: Hotel REITs vs. non-REIT hotel companies. Journal of Real Estate Portfolio Management, 7(1), 79-87.

Nebel, E. C. I., Braunlich, C. G., \& Zhang, Y. (1994). Career paths in American luxury hotels: Hotel food and beverage. International Journal of Contemporary Hospitality Management, 6(6), 3-10.

Nelson, W. A. (2006). The strong building: A case study in direct investment. Managerial Finance, 32(12), 997-1002.

Neuman, W. L. (2003). Social research methods: Qualitative and quantitative approaches. Boston: Pearson. 
Newell, G., \& Peng, H. W. (2007). The significance of leisure property in property portfolios in Australia. Journal of Retail \& Leisure Property, 6(2), 109-116.

Newell, G., \& Seabrook, R. (2006). Factors influencing hotel investment decision making. Journal of Property Investment \& Finance, 24(4), 279-294.

Nichols, M., \& Boutell, M. (2005). The introduction of REITs and their impact on the leisure sector. Journal of Retail \& Leisure Property, 4(4), 295-300.

Norwell, S., \& Mambrino, V. (2006). Banking's top performers 2006. ABA Banking Journal, 98(6), 32-38.

O'Neill, J. W. (2003). ADR rule of thumb: Validity and suffestions for its application. Cornell Hotel and Restaurant Administration Quarterly, 44(4), 7-16.

Oak, S., \& Dalbor, M. C. (2008). Institutional investor preferences for lodging stocks. International Journal of Hospitality Management, 27(1), 3-11.

Page, T. (2007). 'Asset-light' - Managing or leasing? Journal of Retail \& Leisure Property, 6(2), 97-100.

Panvisavas, V., \& Taylor, J. S. (2006). The use of management contracts by international hotel firms in Thailand. International Journal of Contemporary Hospitality Management, 18(3), 231-245.

Pizam, A. (2006). Condominium hotels: A scorching hot lodging product. International Journal of Hospitality Management, 25(2), 167-169.

Property Council of Australia. (2003). New investment frontiers: An industry action plan for reshaping hotel investment. Sydney: Property Council of Australia.

Roberts, E. S. (1999). In defence of the survey method: An illustration from a study of user information satisfaction. Accounting and Finance, 39, 53-77.

Rossman, G. B., \& Wilson, B. L. (1991). Numbers and words revisited: Being "shamelessly eclectic". Evaluation Review, 15(5), 596-619.

Rowe, R. (2005). What could a UK REIT mean for UK hotels? Journal of Retail \& Leisure Property, 5(1), 24-31.

Shaffer, M. A., \& Harrison, D. A. (2001). Forgotten partners of international assignments: Development and test of a model of spuse adjustment. Journal of Applied Psychology, 86(2), 238-254.

Slattery, P. (1996). International development of hotel chains. In R. Kotas, R. Teare, J. Logie, C. Jayawardena \& J. Bowen (Eds.), The International Hospitality Business (pp. 3035). London: Cassell.

Smith Travel Research. (2003). Property and portfolio research. Hotel \& Motel Management, 218(7), 24.

Stewart, R. (2007). Commentary: The Attorney General, the SEC and the Commissioners of Insurance. Journal of Insurance Regulation, 25(3), 79-93.

Sutton, R. I., \& Rafaeli, A. (1998). Untangling the relationship between displayed emotions and organizational sales: The case of convenience stores. Academy of Management Journal, 31(3), 461-487.

Turner, M. J., \& Guilding, C. (2010a). Accounting for the furniture, fittings \& equipment reserve in hotels. Accounting and Finance, 50(4), 967-992.

Turner, M. J., \& Guilding, C. (2010b). Hotel management contracts and deficiencies in owner-operator capital expenditure goal congruency. Journal of Hospitality and Tourism Research, 34(4), 478-511.

Turner, M. J., \& Guilding, C. (2012). Factors affecting biasing of capital budgeting cash flow forecasts: evidence from the hotel industry. Accounting and Business Research, 42(5), 519-545. 
Turner, M. J., \& Guilding, C. (2013). Capital budgeting implications arising from locus of hotel owner/operator power. International Journal of Hospitality Management, 35, 261-273.

Vallen, J. J., \& Vallen, G. K. (1999). Check-in check-out: Managing hotel operations (5th ed.). Upper Saddle River, New Jersey: Pearson Education.

Vallen, J. J., \& Vallen, G. K. (2005). Check-in check-out: Managing hotel operations (7th ed.). Upper Saddle River, New Jersey: Pearson Education.

Wallace, L., \& Cossar, A. (2005). Going private: Public-to-private transactions in the hotel sector in the UK. Journal of Retail \& Leisure Property, 4(1), 39-49.

Wang, K., \& Zhou, Y. (2006). Equilibrium real options exercise strategies with multiple players: The case of real estate markets. Real Estate Economics, 34(1), 1-49.

Warnken, J., Guilding, C., \& Cassidy, K. (2008). A review of the nature and growth of multititled tourism accommodation complexes. International Journal of Hospitality Management, 27, 574-583.

Wilk, R. R. (2001). The impossibility and necessity of re-inquiring: Finding middle ground in social science. Journal of Consumer Research, 28(2), 308-312.

Williams, J. T. (1993). Equilibrium and options on real assets. Review of Financial Studies, 6, 825-850.

Williams, J. T. (1997). Redevelopment of real assets. Real Estate Economics, 25(3), 387-407.

Wolff, C. (2007). Condo-hotel correction. Lodging Hospitality, 63(16), 74-76.

Wong, K. C., \& Norman, G. (1994). The optimal time of renovating a mall. Journal of Real Estate Research, 9(1), 33-48.

Wynne-Smith, M., Adler, A., Hubbard, J., Harle, C., Collins, C., Hetherington, S., . . . Sorgiovanni, F. (2014). Hotel Investment Outlook: Global 2014: Jones Lang LaSalle Hotels.

Younes, E., \& Forster, B. (2006). Middle East hotel markets: Outlook, trends and opportunities and hotel valuation index. Journal of Retail \& Leisure Property, 5(4), 326-337.

Yu, L., \& Huimin, G. (2005). Hotel reform in China: A SWOT analysis. Cornell Hotel and Restaurant Administration Quarterly, 46(2), 153-170. 


\begin{tabular}{|c|c|c|}
\hline \multicolumn{3}{|c|}{$\begin{array}{c}\text { TABLE } 1 \\
\text { Schedule of interviewees }\end{array}$} \\
\hline $\begin{array}{c}\text { Organisation / } \\
\text { hotel location }\end{array}$ & Position & $\begin{array}{c}\text { Key characteristics of interviewee's role in their } \\
\text { organisation or hotel }\end{array}$ \\
\hline Brisbane & CEO & \multirow{5}{*}{$\begin{array}{l}\text { All representing large hotel consulting companies. } \\
\text { Typically working as agents who are engaged as a third- } \\
\text { party by the owner. }\end{array}$} \\
\hline \multirow[t]{2}{*}{ Sydney } & Director & \\
\hline & Director & \\
\hline \multirow[t]{2}{*}{ Sydney } & Director & \\
\hline & Group executive & \\
\hline Brisbane & $\begin{array}{l}\text { Manager hotel } \\
\text { operations }\end{array}$ & $\begin{array}{l}\text { Working as an in-house asset manager employed } \\
\text { directly by hotel owner. }\end{array}$ \\
\hline Sydney & Partner & \multirow{2}{*}{$\begin{array}{l}\text { Considered by several other interviewees to be the two } \\
\text { most prominent lawyers drafting hotel management } \\
\text { contracts in Australia. }\end{array}$} \\
\hline Sydney & Principal & \\
\hline \multirow[t]{2}{*}{ Brisbane } & Partner & \multirow{2}{*}{$\begin{array}{l}\text { Experienced in conducting audits of large listed hotel } \\
\text { owning companies. }\end{array}$} \\
\hline & Partner & \\
\hline Sydney & $\begin{array}{l}\text { Tourism \& hotel } \\
\text { portfolio manager }\end{array}$ & Representative of a large listed property trust owner. \\
\hline \begin{tabular}{|l|} 
Sydney \\
\end{tabular} & Executive & Owner from a large unlisted property trust. \\
\hline \begin{tabular}{|l|} 
Sydney \\
\end{tabular} & Senior fund manager & Owner from a large unlisted property trust. \\
\hline \multirow[t]{2}{*}{ Gold Coast } & General manager & \multirow{2}{*}{$\begin{array}{l}5 \text { star hotel, approximately } 300 \text { rooms, operated under a } \\
\text { management contract by a large international } \\
\text { management company. Strata titled ownership, one large } \\
\text { developer owner owns the majority of strata. }\end{array}$} \\
\hline & Financial controller & \\
\hline \multirow[t]{2}{*}{ Gold Coast } & General manager & \multirow[b]{2}{*}{$\begin{array}{l}\text { 3.5 star hotel, approximately } 400 \text { rooms. Until 2006, was } \\
\text { operated under a management contract by a large } \\
\text { international management company. Owner was a high } \\
\text { net worth individual. Hotel now owned by developer } \\
\text { and run independently. General manager and financial } \\
\text { controller remain the same under new ownership. }\end{array}$} \\
\hline & Financial controller & \\
\hline Gold Coast & General manager & $\begin{array}{l}5 \text { star hotel, approximately } 300 \text { rooms, owned by } \\
\text { developer, managed independently. General manager } \\
\text { has extensive experience with a range of hotel types, } \\
\text { including several operating under management } \\
\text { contracts. }\end{array}$ \\
\hline \multirow[t]{2}{*}{ Gold Coast } & General manager & \multirow{2}{*}{$\begin{array}{l}4 \text { star hotel, approximately } 300 \text { rooms, operated under a } \\
\text { management contract by a large international } \\
\text { management company, owned by a developer. }\end{array}$} \\
\hline & Financial controller & \\
\hline
\end{tabular}

Note: room numbers have been rounded to the nearest " 50 " to protect interviewee anonymity. 


\begin{tabular}{|c|c|c|c|c|}
\hline \multicolumn{5}{|c|}{$\begin{array}{l}\text { TABLE } 2 \\
\text { Hotel ownership characteristics and investment time horizon in Australia }\end{array}$} \\
\hline $\begin{array}{l}\text { Category of } \\
\text { hotel owner }\end{array}$ & $\begin{array}{l}\text { Public } \\
\text { vs. } \\
\text { private }\end{array}$ & $\begin{array}{c}\text { Hotel } \\
\text { owner } \\
\text { examples }\end{array}$ & Characteristics & $\begin{array}{c}\text { Investment time } \\
\text { horizon }\end{array}$ \\
\hline $\begin{array}{l}\text { Unlisted } \\
\text { property } \\
\text { trusts }\end{array}$ & Private & $\begin{array}{l}\text { TAHL }{ }^{7} ; \\
\text { Colonial } \\
\text { First } \\
\text { State; } \\
\text { Eureka. }\end{array}$ & $\begin{array}{l}\text { - Short-term performance less critical because not valued by the share } \\
\text { market. } \\
\text { - Year-to-year performance still critical to unit holders who look for an } \\
\text { annual dividend. } \\
\text { - Typically private companies and not listed on the stock exchange. }\end{array}$ & $\begin{array}{l}\text { Medium term: }>5 \\
\text { years }<10 \text { years }\end{array}$ \\
\hline $\begin{array}{l}\text { Listed } \\
\text { property } \\
\text { trusts }\end{array}$ & Public & $\begin{array}{l}\text { GPT } \\
\text { Group; } \\
\text { Thakral; } \\
\text { Mirvac. }\end{array}$ & $\begin{array}{l}\text { - Invest in various classes of real estate (of which hotels is only one class). } \\
\text { - Diversification of real estate investment spreads risk so returns from } \\
\text { hotels not as critical to overall return on investment. } \\
\text { - Typically public companies listed on the stock exchange. }\end{array}$ & $\begin{array}{l}\text { Medium term: }>5 \\
\text { years }<10 \text { years }\end{array}$ \\
\hline $\begin{array}{l}\text { Specific } \\
\text { listed } \\
\text { property } \\
\text { trusts }\end{array}$ & Public & $\begin{array}{l}\text { Grand } \\
\text { Hotel } \\
\text { Group; } \\
\text { CDL } \\
\text { REIT }^{8}\end{array}$ & $\begin{array}{l}\text { - } \text { Invest solely in hotels } \\
\text { - } \quad \text { Highly educated investors. } \\
\text { - } \quad \text { Listed stocks are valued every day by the market so highly tuned to } \\
\text { - } \quad \text { Lerformance. } \\
\text { - hotels. } \\
\text { - Typically public companies listed on the stock exchange. }\end{array}$ & $\begin{array}{l}\text { Medium term: }>5 \\
\text { years }<10 \text { years }\end{array}$ \\
\hline $\begin{array}{l}\text { Specialist } \\
\text { hotel } \\
\text { management } \\
\text { companies }\end{array}$ & $\begin{array}{l}\text { Public or } \\
\text { private }\end{array}$ & $\begin{array}{l}\text { Accor; } \\
\text { Hilton; } \\
\text { Sheraton; } \\
\text { Westin; } \\
\text { IHG. }^{9}\end{array}$ & $\begin{array}{l}\text { - Invest in and operate hotels. } \\
\text { - Typically interested in owning hotels that can deliver superior returns } \\
\text { than if only operated (which is becoming increasingly rare). } \\
\text { - Can be public companies that are either listed or not listed on the stock } \\
\text { exchange or private companies. }\end{array}$ & Variable \\
\hline
\end{tabular}

\footnotetext{
${ }^{7}$ TAHL stands for "Tourism Asset Holdings Limited".

${ }^{8}$ CDL REIT stands for "CDL Real Estate Investment Trust".

${ }^{9}$ IHG stands for "Intercontinental Hotels Group”.
} 


\begin{tabular}{|c|c|c|c|c|}
\hline $\begin{array}{l}\text { Opportunity } \\
\text { funds }\end{array}$ & Public & $\begin{array}{l}\text { Morgan } \\
\text { Stanley; } \\
\text { Walton } \\
\text { Street. }\end{array}$ & $\begin{array}{l}\text { - Mostly made up of investment banks. } \\
\text { - Try to find a 'story' in their investment (e.g. a turnaround story). } \\
\text { - Typically have a specified time period 'window' to sell the asset, which } \\
\text { is usually less than } 5 \text { years. } \\
\text { - Can roll-over investment into a new fund if investors agree. } \\
\text { - Aim to add value and move on. } \\
\text { - } \text { Asset sold at peak value rather than when it suits. } \\
\text { - Typically public companies listed on the stock exchange. }\end{array}$ & $\begin{array}{l}\text { Short-term: }<5 \\
\text { years }\end{array}$ \\
\hline Developers & Public & $\begin{array}{l}\text { City } \\
\text { Pacific } \\
\text { Ltd; } \\
\text { Sunland } \\
\text { Group; } \\
\text { Raptis } \\
\text { Group. }\end{array}$ & $\begin{array}{l}\text { Typically purchase a hotel to do one or more of the following: } \\
\text { 1. Acquire the land upon which the hotel stands. } \\
\text { 2. Reposition the hotel and then sell off the rooms as strata apartments. } \\
\text { 3. Demolish and rebuild the hotel. } \\
\text { 4. Demolish and construct a building with an alternative use on the site. } \\
\text { 5. Retain the hotel until capital appreciation of the land warrants sale of the } \\
\text { hotel. } \\
\text { 6. Retain the hotel until macroeconomic conditions warrant the initiation of } \\
\text { development plans. } \\
\text { 7. Retain the hotel until microeconomic conditions warrant the initiation of } \\
\text { development plans. } \\
\text { - Purchase often made as part of a joint venture where one party maintains } \\
\text { the hotel for a specified time period whilst the other party organises } \\
\text { developments to the site. } \\
\text { - Typically very business-like with a high appreciation of economic } \\
\text { realities. } \\
\text { - Increasing presence in Australia. } \\
\text { Investment time horizon can be as short as a couple of months to over } \\
\text { ten years, depending on the reason for purchase. } \\
\text { Typically public companies and listed on the stock exchange. }\end{array}$ & Variable \\
\hline Strata-title & $\begin{array}{l}\text { Typically } \\
\text { private }\end{array}$ & $\begin{array}{l}\text { Low net } \\
\text { worth } \\
\text { private }\end{array}$ & $\begin{array}{l}\text { - Typically purchase a hotel as both an investment and a place to spend } \\
\text { their holidays. } \\
\text { - Typically private }\end{array}$ & Variable \\
\hline
\end{tabular}




\begin{tabular}{|c|c|c|c|c|}
\hline & & investors & & \\
\hline $\begin{array}{l}\text { Institutional } \\
\text { owners }\end{array}$ & Public & $\begin{array}{l}\text { AMP; } \\
\text { GIC; } \\
\text { NRMA. }\end{array}$ & $\begin{array}{l}\text { - Short-term required returns are low due to use of life insurance funding. } \\
\text { - Usually have obligations toward shareholders and investors. } \\
\text { - Focus is on long-term consistency of returns. } \\
\text { - Traditionally risk averse. } \\
\text { - Typically public companies that are listed on the stock exchange. }\end{array}$ & $\begin{array}{l}\text { Long-term: > } 10 \\
\text { years }\end{array}$ \\
\hline $\begin{array}{l}\text { High net } \\
\text { worth private } \\
\text { investors }\end{array}$ & $\begin{array}{l}\text { Public or } \\
\text { private }\end{array}$ & $\begin{array}{l}\text { Mulpha; } \\
\text { Stamford } \\
\text { CKR. }\end{array}$ & $\begin{array}{l}\text { - Ostentatious - wanting to showcase hotel ownership. } \\
\text { - Focus on upscale luxury hotels in very good condition. } \\
\text { - Generally lack any long-term strategic motives or development plans. } \\
\text { - Very difficult to characterise the rationale for ownership as it might be } \\
\text { heavily ego oriented, in which case decision-making can often be } \\
\text { irrational. } \\
\text { - Generally have a 'money is no object' mentality so that 'their hotel is the } \\
\text { greatest'. } \\
\text { - Typically made up of private individuals but can be a public company } \\
\text { but would not normally be listed on the stock exchange. }\end{array}$ & Variable \\
\hline
\end{tabular}




\begin{tabular}{|c|c|c|c|c|}
\hline \multicolumn{5}{|c|}{$\begin{array}{c}\text { TABLE } 3 \\
\text { Summary of survey replies }\end{array}$} \\
\hline & \multicolumn{2}{|c|}{ Country } & \multirow[b]{2}{*}{$\begin{array}{c}\text { Total } \\
\text { (n) }\end{array}$} & \multirow[b]{2}{*}{$\begin{array}{l}\text { Response } \\
\text { rate }\end{array}$} \\
\hline & $\begin{array}{l}\text { Australia } \\
\text { (n) }\end{array}$ & $\begin{array}{c}\text { New } \\
\text { Zealand } \\
\text { (n) }\end{array}$ & & \\
\hline First mailing & 55 & 28 & 83 & $13.37 \%$ \\
\hline Second mailing & 36 & 11 & 47 & $7.57 \%$ \\
\hline Industry distribution & 41 & 10 & 51 & $8.21 \%$ \\
\hline Emailing & 10 & 6 & 16 & $2.58 \%$ \\
\hline Telephone & 3 & 0 & 3 & $0.48 \%$ \\
\hline $\begin{array}{l}\text { Total number of } \\
\text { responses }\end{array}$ & 145 & 55 & 200 & \\
\hline $\begin{array}{l}\text { Total number in } \\
\text { sample }\end{array}$ & 437 & 184 & 621 & \\
\hline Total response rate & & & & $32.21 \%$ \\
\hline
\end{tabular}


TABLE 4

Distinct hotel operational characteristics by hotel owner type across Australia and New Zealand sample

\begin{tabular}{|c|c|c|c|c|c|c|c|c|c|c|c|c|}
\hline \multirow[b]{2}{*}{ Hotel owner category } & \multirow[b]{2}{*}{ Incidence } & \multicolumn{4}{|c|}{ Hotel ownership / Management Structure } & \multicolumn{7}{|c|}{ Hotel operational characteristics } \\
\hline & & $\begin{array}{l}\text { Owner- } \\
\text { Operator }^{\mathrm{B}}\end{array}$ & \begin{tabular}{|l|} 
Management \\
Contract
\end{tabular} & Franchise & Other $^{\mathrm{C}}$ & Star-rating & Hotel age & $\begin{array}{l}\text { Years } \\
\text { GM }\end{array}$ & $\begin{array}{l}\text { Hotel size } \\
\text { rooms }\end{array}$ & $\begin{array}{l}\text { Hotel size } \\
\text { turnover } \\
\text { (AUD \$ } \\
\text { million) } \\
\end{array}$ & $\begin{array}{l}\text { Hotel } \\
\text { owner size } \\
\text { (number of } \\
\text { hotels) }\end{array}$ & $\begin{array}{l}\text { Hotel owner } \\
\text { size (number of } \\
\text { hotel rooms) }\end{array}$ \\
\hline Unlisted property trust & $13(6.5 \%)$ & 3 & 9 & 1 & - & 4.04 & $30.23+\dagger \dagger$ & 3.08 & 235 & 21.94 & $11.75^{* * *}$ & $1684.91 * *$ \\
\hline Listed property trust & $27(13.5 \%)$ & 8 & 16 & 1 & 2 & 4.17 & 24.06 & 4.25 & 193 & 15.16 & 156.87 & 17149.92 \\
\hline Specific listed property trust & $6(3 \%)$ & 2 & 4 & - & - & 4.33 & 25.67 & 4.17 & 222 & 16.25 & 18.33 & 3000.00 \\
\hline Opportunity fund & $3(1.5 \%)$ & - & 2 & 1 & - & 4.33 & 20.00 & 2.83 & 273 & 23.00 & 140.67 & $31455.00 \dagger \dagger$ \\
\hline $\begin{array}{l}\text { Traditional investment } \\
\text { institution }\end{array}$ & $5(2.5 \%)$ & 1 & 3 & - & 1 & 4.50 & 19.40 & 5.25 & 217 & 27.14 & $4.00^{* * *}$ & $2075.00 * *$ \\
\hline $\begin{array}{l}\text { Specialist hotel management } \\
\text { company }\end{array}$ & $47(23.5 \%)$ & 21 & 21 & 2 & 3 & 4.16 & 21.17 & $2.43^{*}$ & 170 & 13.22 & $1132.80 \dagger$ & $70511.35 \dagger$ \\
\hline Developer & $23(11.5 \%)$ & 7 & 12 & 4 & - & 4.23 & $13.17 *$ & 3.07 & $150^{* *}$ & $9.64 *$ & $3.10^{* * * *}$ & $458.70^{*}$ \\
\hline Strata-titled ownership & $15(7.5 \%)$ & 2 & 10 & 2 & 1 & 4.31 & $11.97 *$ & 3.52 & 182 & $9.93^{*}$ & $5.55^{* * *}$ & 838.82* \\
\hline $\begin{array}{l}\text { High net worth private } \\
\text { investor }\end{array}$ & $54(27 \%)$ & 28 & 19 & 7 & - & 4.11 & $30.95 \dagger \dagger$ & 4.92 & $155^{* *}$ & $8.86^{*}$ & $2.55^{* * * *}$ & 414.84* \\
\hline Other $^{A}$ & 7 (3.5\%) & 2 & 5 & - & - & 4.14 & 17.86 & 8.54 & 177 & 21.71 & 984.75 & $1550.67^{* *}$ \\
\hline Total & $200(100 \%)$ & \begin{tabular}{|l|l}
$74 \%)$ \\
\end{tabular} & \begin{tabular}{|l|l}
$101(50.5 \%)$ \\
\end{tabular} & $18(9 \%)$ & 7 (3.5\%) & - & - & - & - & - & - & - \\
\hline Average & - & - & - & - & - & 4.17 & 23.17 & 3.90 & 180 & 12.98 & 323.36 & 19360.87 \\
\hline
\end{tabular}

${ }^{\text {A }}$ Of the $3.5 \%(n=7)$ respondents that responded "other”, responses were as follows: (1) joint venture, combining a developer and a specific listed property trust; (2) hotel is currently under receivership; (3) hybrid mix, strata titled / timeshare / developer; (4) owned by timeshare club - right to use; (5) local government - local Maori Tribe; (6) sovereign wealth fund. One respondent did not provide any comment.

${ }^{\text {B }}$ A Chi-square test for independence indicated no significant association between hotel ownership / management structure and hotel owner categories, $\mathrm{X}^{2}$ (27, $\left.\mathrm{n}=200\right)=$ 34.343, $p=.156$, phi $=.414$ )

${ }^{\mathrm{C}}$ Of the 3.5\% $(n=7)$ respondents that responded "other”, six indicated their hotels operated under a lease. One respondent did not provide any comment. 
† Statistically significantly higher than remainder of the sample $(p<.01)$.

†† Statistically significantly higher than remainder of the sample $(p<.05)$.

$\dagger \dagger+$ Statistically significantly higher than remainder of the sample $(p<.10)$

* Statistically significantly lower than remainder of the sample $(p<.01)$.

** Statistically significantly lower than remainder of the sample $(p<.05)$.

$* * *$ Statistically significantly lower than remainder of the sample $(p<.10)$.

A one-way between groups ANOVA with planned comparisons was used in the cross-owner group tests of continuous variables for statistically significant differences. 